Louisiana State University

LSU Digital Commons

Faculty Publications

Department of Biological Sciences

$9-1-2005$

\title{
A climate-based approach to the restoration of fire-dependent ecosystems
}

\author{
Brian Beckage \\ University of Vermont \\ William J. Platt \\ Louisiana State University \\ Bob Panko \\ Everglades National Park
}

Follow this and additional works at: https://digitalcommons.Isu.edu/biosci_pubs

\section{Recommended Citation}

Beckage, B., Platt, W., \& Panko, B. (2005). A climate-based approach to the restoration of fire-dependent ecosystems. Restoration Ecology, 13 (3), 429-431. https://doi.org/10.1111/j.1526-100X.2005.00070.x

This Article is brought to you for free and open access by the Department of Biological Sciences at LSU Digital Commons. It has been accepted for inclusion in Faculty Publications by an authorized administrator of LSU Digital Commons. For more information, please contact ir@lsu.edu. 


\title{
A Climate-Based Approach to the Restoration of Fire-Dependent Ecosystems
}

\author{
Brian Beckage, ${ }^{1,2}$ William J. Platt, ${ }^{3}$ and Bob Panko ${ }^{4}$
}

\begin{abstract}
Recurrent fires are integral to the function of many ecosystems worldwide. The management of fire-frequented ecosystems requires the application of fire at the appropriate frequency and seasonality, but establishing the natural fire regime for an ecosystem can be problematic. Historical records of fires are often not available, and surrogates
\end{abstract}

for past fires may not exist. We suggest that the relationship between climate and fire can provide an alternative means for inferring past fire regimes in some ecosystems.

Key words: climate, ecosystem management, El Niño, ENSO, fire, La Niña, restoration.
Fire plays a critical role in the restoration and maintenance of many ecosystems. When and how often to apply fire continues to be controversial (e.g., Lockwood et al. 2003; Maehr \& Larkin 2004), and fire management has been identified as a critical area of research for preservation of wilderness ecosystems (Cole \& Landres 1996). Although fire suppression leads to the degradation of fire-dependent ecosystems, fires that occur at a frequency or season outside the natural fire regime also have negative effects on community structure and species composition (Platt et al. 1988; Seamon et al. 1989; Glitzenstein et al. 1995; Platt et al. 2002). The restoration and management of firedependent ecosystems requires ecologically appropriate fire management that, ideally, should be based on natural fire regimes (Cissel et al. 1999). Defining the natural fire regime is usually difficult, however, because of the absence of historical data on the timing and frequency of fire.

The greater Everglades ecosystem in southern Florida, for example, is a fire-frequented landscape that is in the midst of a large-scale and long-term restoration. Restoration efforts have largely focused on reestablishing a more natural hydrology, but the reestablishment of natural fire regimes also needs to be addressed if the Everglades restoration is to be successful (Lockwood et al. 2003). Data on historic fire regimes in southern Florida are lacking prior to the establishment of Everglades National Park in 1948, and fire histories cannot be reconstructed from dendrochonological records because trees do not reliably produce annual rings in the subtropical environment. Even the definition of the "natural" fire regime is controversial

\footnotetext{
${ }^{1}$ Department of Botany, University of Vermont, Marsh Life Science Building, Burlington, VT 05405, U.S.A.

${ }^{2}$ Address correspondence to B. Beckage, email brian.beckage@uvm.edu

${ }^{3}$ Department of Biological Sciences, Louisiana State University, Baton Rouge,

LA 70803, U.S.A.

${ }^{4}$ Everglades National Park, 40001 State Route 9336, Homestead, FL 33034, U.S.A.
}

(C) 2005 Society for Ecological Restoration International in the southeastern United States because paleo-Indians are thought to have ignited fires, leading to debate over whether these fires should be considered part of the natural fire regime (Williams 2003). The Everglades restoration depends on reestablishment of a natural fire regime, but how can that fire regime be inferred?

One approach to identifying natural fire regimes has been to experimentally measure the responses of individual species and communities to particular fire regimes (e.g., Platt et al. 1988; Brewer \& Platt 1994). The natural fire regime is presumed to be the one to which species most strongly and positively respond; the underlying assumption is that many (but not necessarily all) species have adapted to the prevailing natural fire regime. This "biotic" approach to inferring natural fire regimes is research intensive, requiring long-term study of species responses to fires implemented over different seasons and frequencies but has been applied in the southeastern United States via large-scale experiments spanning decades (e.g., Waldrop et al. 1992; Glitzenstein et al. 1995). However, data from extensive fire experiments are often not available for large landscapes such as the Everglades. In addition, experimentally imposed fire frequencies can be confounded with past fire history (Streng et al. 1993), resulting in responses that differ between the time period in which fires are reintroduced following suppression and during subsequent maintenance of frequent fires (a hysteresis). Such differences in response to fire confound our ability to infer historic fire regimes reliably using changes in community composition. For example, a fire return interval of as long as 15 years could be estimated for Everglades' rockland pine savannas from the slow process of hardwood encroachment into pine savannas (e.g., Lockwood et al. 2003). In contrast, fuel loads and species responses in rockland pine savannas restored by extirpation of established hardwoods in lightning-season fires indicate a shorter fire return interval of as little as 2-4 years (Snyder et al. 1990; Slocum et al. 2003). 
Nor can historic fire regimes be reliably inferred from present distributions of species (e.g., Lockwood et al. 2003). Species populations differentially shift across the landscape in response to changing environmental conditions and fire regimes (e.g., Drewa et al. 2002), so that the current distribution of species populations may be substantially different from historic distributions. In the Everglades, changes in the distributions of plant and animal populations have occurred following anthropogenic alteration of hydrology (Light \& Dineen 1994), and the rate at which organisms adjust their spatial distribution to changing environmental conditions is species specific. Mobile organisms or plant/animal species with short generation times (like the Cape Sable Seaside sparrow; Curnutt et al. 1998) adjust more rapidly to altered disturbance regimes than less mobile or long-lived species (like South Florida Slash pine; Platt et al. 2000). This differential species inertia could lead to potentially contradictory natural fire regimes being inferred for a landscape depending on the organism considered. Management of ecosystems that is based on the fire responses of particular species in their current distributions will likely lead to conflict when agencies and researchers look to different species for guidance in determining natural fire regimes - the fire regime that is optimal for one species may be less than optimal for another (e.g., Maehr \& Larkin 2004; Beckage et al. 2005).

We suggest that the natural coupling of climate to fire can provide a basis for inferring natural fire regimes, including both fire frequency and season, as well as for restoring fire-dependent ecosystems. The relationship between climate and fires regime in southern Florida, for instance, has recently been established (Beckage et al. 2003) and can even be used to predict the potential for severe wildfires months in advance (Beckage \& Platt 2003). Fire regimes in the Everglades are strongly linked to the El Niño Southern Oscillation (ENSO) through effects on precipitation and lightning strike frequency. More than $70 \%$ of the area burned each year in the Everglades occurs during the spring transition from dryto wet-season conditions when water levels are at their lowest levels and lightning strikes from the onset of the summer thunderstorms provide an ignition source. ENSO cycles drive interannual variability in wildfire severity by either intensifying (La Niña) or ameliorating (El Niño) the winter dry season (Beckage et al. 2003; Ropelewski \& Halpert 1986) and by increasing (La Niña) or decreasing (El Niño) lightning strike frequency. Increased numbers of lightning strikes and severe drought conditions both occur during La Niña events, leading to large areas burned (Beckage et al. 2003). The tight coupling of climate and fire in the Everglades is likely to extend throughout much of the southeastern United States (Simard et al. 1985; Brenner 1991); thus, climate-fire relationships should provide a general basis for understanding the natural seasonality and frequency of fire. The recogni- tion that climate creates the abiotic template driving natural fire regimes also lessens the importance of distinguishing between paleo-Indian-initiated and lightinginitiated fires-large fires are only likely to occur when climatic conditions are suitable, regardless of ignition source (Taylor 1981; Beckage et al. 2003). Fire models that emphasize the underlying role of climate (e.g., Beckage \& Platt 2003) can provide the basis for inferring fire regimes beyond historical fire records using data on past climate, such as ENSO reconstructions over the past thousands of years (Tudhope et al. 2001).

Although climate provides the template for natural fire regimes, the conditions under which historic fire regimes occurred have been modified by anthropogenic influences. Conversion of natural landscapes to urban areas, for example, has fragmented the landscape and decreased the frequency and size of fires compared to natural conditions. In the Everglades, widespread rockland pine savannas on the eastern border (Snyder et al. 1990) were a likely source of frequent fires because of xeric conditions during the dry- to wet-season transition (Slocum et al. 2003), the abundance of rapidly drying, volatile fine fuels (Platt 1999), and the predominate westerly direction of most large fires (approximately 85\%) recorded in the Everglades. The loss of these coastal ridge savannas by urban development has eliminated a likely source of natural fires in the greater Everglades ecosystem. We note that anthropogenic-driven climate change is expected to influence the ENSO cycle, resulting in a semipermanent El Niño state (Timmermann et al. 1999) and lowered fire frequency in the southeastern United States; such changes may be accompanied by shifts in community structure and loss of fire-adapted species. The combined anthropogenic effects of landscape fragmentation and global climate change will be to reduce Everglades' fire regimes below historic frequencies and areas burned. The continued existence of these fire-adapted communities in light of ongoing anthropogenic change will require a vigorous prescribed fire program that mimics natural fire regimes by incorporating intra- and interannual variation in historic climate cycles such as ENSO.

In conclusion, we propose that the relationship between climate and fire provides an independent and unbiased basis for deducing natural fire regimes, and their variability, for the restoration and management of firefrequented landscapes. The climatic approach to inferring fire regimes provides an alternative to either relying on proxy records of past fire events, which are often not available, or on the responses of specific species to particular fire regimes, which may be biased and inconsistent across taxa. Climate cycles are linked to fire regimes in geographically diverse ecosystems (e.g., Swetnam \& Betancourt 1990; van der Werf et al. 2004), so climatefire relationships may be widely applicable to the management and restoration of fire-dependent ecosystems worldwide. 


\section{LITERATURE CITED}

Beckage, B., J. Comiskey, and S. Duke-Sylvester. 2005. Natural fire regimes in southern Florida. Natural Areas Journal 25:6-8.

Beckage, B., and W. J. Platt. 2003. Predicting severe wildfire years in the Florida Everglades. Frontiers in Ecology and the Environment 1:235-239.

Beckage, B., W. J. Platt, M. G. Slocum, and B. Panko. 2003. Influence of the El Niño-Southern Oscillation on fire regimes in the Florida Everglades. Ecology 84:3124-3130.

Brenner, J. 1991. Southern Oscillation anomalies and their relation to Florida wildfires. The International Journal of Wildland Fire 1:73-78.

Brewer, J. S., and W. J. Platt. 1994. Effects of fire season and soil fertility on clonal growth in a pyrophilic forb, Pityopsis graminifolia (Asteraceae). American Journal of Botany 81:805-814.

Cissel, J. H., F. J. Swanson, and P. J. Weisberg. 1999. Landscape management using historical fire regimes: Blue River, Oregon. Ecological Applications 9:1217-1231.

Cole, D. N., and P. B. Landres. 1996. Threats to wilderness ecosystems: impacts and research needs. Ecological Applications 6:168-184.

Curnutt, J. L., A. L. Mayer, T. M. Brooks, L. Manne, O. L. Bass Jr, D. M. Flemming, M. P. Nott, and S. L. Pimm. 1998. Population dynamics of the endangered Cape Sable seaside-sparrow. Animal Conservation 1:11-21.

Drewa, P. B., W. J. Platt, and E. B. Moser. 2002. Fire effects on resprouting of shrubs in southeastern longleaf pine savannas. Ecology 83: 755-767.

Glitzenstein, J. S., W. J. Platt, and D. R. Streng. 1995. Effects of fire regime and habitat on tree dynamics in north Florida longleaf pine savannas. Ecological Monographs 65:441-476.

Light, S. S., and J. W. Dineen. 1994. Water control in the Everglades: a historical perspective. Pages $47-84$ in S. M. Davis, and J. C. Ogden, editors. Everglades: the ecosystem and its restoration. St. Lucie Press, Delray Beach, Florida.

Lockwood, J. L., M. S. Ross, and J. P. Sah. 2003. Smoke on the water: the interplay of fire and water flow on Everglades restoration. Frontiers in Ecology and the Environment 1:462-468.

Maehr, D. S., and J. L. Larkin. 2004. Do prescribed fires in south Florida reduce habitat quality of native carnivores? Natural Areas Journal 24:188-197.

Platt, W. J. 1999. Southeastern pine savannas. Pages 23-51 in R. C. Anderson, J. S. Fralish, and J. M. Baskin, editors. Savannas, barrens, and rock outcrop plant communities of North America. Cambridge University Press, Cambridge, United Kingdom.

Platt, W. J., B. Beckage, R. F. Doren, and H. H. Slater. 2002. Interactions of large-scale disturbances: prior fire regimes and hurricane mortality of savanna pines. Ecology 83:1566-1572.
Platt, W. J., R. F. Doren, and T. Armentano. 2000. Effects of Hurricane Andrew on stands of slash pine (Pinus elliottii var. densa) in the Everglades region of south Florida (USA). Plant Ecology 146:43-60.

Platt, W. J., G. W. Evans, and M. M. Davis. 1988. Effects of fire season on flowering of forbs and shrubs in longleaf pine forests. Oecologia 76:353-363.

Ropelewski, C. F., and M. S. Halpert. 1986. North American precipitation and temperature patterns associated with the El Niño/Southern Oscillation (ENSO). Monthly Weather Review 114:2352-2362.

Seamon, P. A., R. L. Myers, L. E. Robbins, and G. S. Seamon. 1989. Wiregrass reproduction and community restoration. Natural Areas Journal 9:264-265.

Simard, A. J., D. A. Haines, and W. A. Main. 1985. Relations between El Niño/Southern Oscillation anomalies and wildland fire activity in the United States. Agricultural and Forest Meteorology 36:93-104.

Slocum, M. G., W. J. Platt, and H. C. Cooley. 2003. Effects of differences in prescribed fire regimes on patchiness and intensity of fires in subtropical savannas of Everglades National Park, Florida. Restoration Ecology 11:91-102.

Snyder, J. R., A. Herndon, and W. B. Robertson Jr. 1990. South Florida rockland ecosystems: tropical hammocks and pinelands. Pages 230-274 in R. Myers, and J. Ewel, editors. Ecosystems of Florida. University of Central Florida Press, Orlando.

Streng, D. R., Glitzenstein, J. S., and Platt, W. J. 1993. Evaluating effects of season of burn in longleaf pine forests: a critical review and some results from an ongoing long term study. Proceedings of the Tall Timbers Fire Ecology Conference 18:227-259.

Swetnam, T. W., and J. L. Betancourt. 1990. Fire-Southern Oscillation relations in the southwestern United States. Science 249:1017-1020.

Taylor, D. L. 1981. Fire history and fire records for Everglades National Park, 1948-1979. South Florida Research Center Report T-619. U.S. National Park Service, Department of the Interior.

Timmermann, A., J. Oberhuber, A. Bacher, M. Esch, M. Latif, and E. Roeckner. 1999. Increased El Niño frequency in a climate model forced by future greenhouse warming. Nature 398:694-697.

Tudhope, A. W., C. P. Chilcott, M. T. McCulloch, E. R. Cook, J. Chappell, R. M. Ellam, D. W. Lea, J. M. Lough, and G. B. Shimmield. 2001. Variability in the El Niño-Southern Oscillation through a glacial-interglacial cycle. Science 291:1511-1517.

van der Werf, G. R., J. T. Randerson, G. J. Collatz, L. Giglio, P. S. Kasibhatla, A. F. Arellano Jr, S. C. Olsen, and E. S. Kasischke. Continental-scale partitioning of fire emissions during the 1997 to $2001 \mathrm{El} \mathrm{Nino/La} \mathrm{Nina} \mathrm{period.} \mathrm{Science} \mathrm{303:73-76.}$

Waldrop, T. A., D. L. White, and S. M. Jones. 1992. Fire regimes for pinegrassland communities in the southeastern United States. Forest Ecology and Management 47:195-210.

Williams, M. 2003. Deforesting the earth: from prehistory to global crisis. University of Chicago Press, Chicago, Illinois. 